\title{
Molecular Imaging of Heparan Sulfate Expression with Radiolabeled Recombinant Eosinophil Cationic Protein Predicts Allergic Lung Inflammation in a Mouse Model for Asthma
}

\author{
Hui-Chen Chen ${ }^{1 *}$, Hao-Teng Chang ${ }^{2 *}$, Po-Han Huang ${ }^{1}$, Margaret Dah-Tsyr Chang ${ }^{3}$, Ren-Shyan Liu ${ }^{4}$, Yu-Jung Lin ${ }^{1}$, \\ and Chia-Hung Hsieh ${ }^{1,5}$ \\ ${ }^{1}$ Graduate Institute of Basic Medical Science, China Medical University, Taichung, Taiwan; ${ }^{2}$ Graduate Institute of Molecular Systems \\ Biomedicine, China Medical University, Taichung, Taiwan; ${ }^{3}$ Institute of Molecular and Cellular Biology and Department of Medical \\ Science, National Tsing Hua University, Hsinchu, Taiwan; ${ }^{4}$ Department of Nuclear Medicine, Taipei Veterans General Hospital, \\ Taipei, Taiwan; and ${ }^{5}$ Department of Medical Research, China Medical University Hospital, Taichung, Taiwan
}

\begin{abstract}
Heparan sulfate proteoglycans (HSPGs) are glycoproteins consisting of a core protein to which linear heparan sulfate (HS) side chains are covalently attached. These HS side chains mediate a variety of biologic functions involved in inflammation. Radionuclide imaging of HS side chains in tissues with inflammation may be used for the stratification of patients who would most likely benefit from HSPG-targeting therapy. The goal of this study was to evaluate the feasibility of in vivo radionuclide imaging of HS side chain expression in a mouse model of asthma using the recombinant eosinophil cationic protein (rECP). Methods: rECP was radioiodinated with 125 or ${ }^{123}$ I using the Chloramine-T method. The $50 \%$ inhibitory concentration value for ${ }^{125}$-labeled rECP was determined in a competitive cell-binding assay using Beas-2B cells. The binding of radiolabeled rECP to HS side chains was evaluated both in vitro and in vivo. The biodistribution of radiolabeled rECP was assessed in asthma mice or in control mice using SPECT imaging, ex vivo biodistribution measurements, and microautoradiography. Results: The 50\% inhibitory concentration value for ${ }^{125} \mathrm{I}-\mathrm{rECP}$ was $7.4 \pm 0.1 \mathrm{nM}$. The loss of HS side chains substantially inhibited the cellular and tissue uptake of ${ }^{125}$ - or ${ }^{123} \mathrm{I}-\mathrm{rECP}$, indicating that HS side chains of HSPGs are required for ${ }^{125} \mathrm{I}$ - or ${ }^{123} \mathrm{I}$-eosinophil cationic protein binding and uptake both in vitro and in vivo. SPECT imaging demonstrated an appreciably higher accumulation of radioactivity in the lungs of asthma mice than in those of control mice. Ex vivo biodistribution studies also confirmed that there was at least a 4-fold increase in the lung-to-muscle ratio of asthma mice, compared with control mice. The accumulation of radiolabeled rECP was linearly correlated with leukocyte infiltration. Conclusion: This study illustrates the feasibility of using radiolabeled rECP for the visualization of HS side chains of HSPGs and the evaluation of allergic lung inflammation in living subjects. Our data indicate that radiolabeled $\mathrm{rECP}$ is a novel imaging agent for $\mathrm{HS}$ side chains of HSPGs in predicting allergic lung inflammation in living mice.
\end{abstract}

Received Jul. 18, 2012; revision accepted Nov. 26, 2012.

For correspondence or reprints contact: Chia-Hung Hsieh, No. 91, HsuehShih Rd., Taichung 404, Taiwan.

E-mail: chhsiehcmu@mail.cmu.edu.tw

${ }^{*}$ Contributed equally to this work.

Published online Mar. 21, 2013.

COPYRIGHT (C 2013 by the Society of Nuclear Medicine and Molecular Imaging, Inc.
Key Words: heparan sulfate proteoglycans; allergic inflammation; recombinant eosinophil cationic protein; asthma, single-photon emission computed tomography

J Nucl Med 2013; 54:793-800

DOI: 10.2967/jnumed.112.111393

\section{$\mathbf{H}$} eparan sulfate proteoglycans (HSPGs) are abundant cell-surface molecules that are part of the extracellular matrix (1). HSPGs consist of a protein core (such as syndecan or glypicans) covalently attached to heparan sulfate (HS) side chains, which are linear carbohydrate polymers. $\mathrm{Nu}-$ merous biochemical and cell culture assays have suggested that HSPGs are involved in a variety of biologic phenomena (e.g., organogenesis, embryonic development, angiogenesis, regulation of blood coagulation, cell adhesion, and lipid metabolism) because of their ability to bind to various proteins or peptides such as growth factors, chemokines, interleukins, enzymes, inhibitors, and plasma proteins (1-3). Moreover, both the protein core and the HS side chains of HSPGs are involved in several disease processes related to cancer and inflammation. Many studies have shown that these molecules serve as potential biomarkers for cancer and inflammation $(4,5)$. In addition, there is substantial interest in targeting HSPGs for cancer or inflammation treatment $(6,7)$. However, the lack of appropriate noninvasive tools is currently the main limitation for monitoring in vivo HSPG expression in HSPG-related disease progression.

Increasing evidence suggests that HS side chains of HSPGs modulate cytokine function to coordinate the inflammatory response $(8,9)$. HS interacts with a series of inflammatory chemokines and cytokines, which congregate and present chemoattractants $(1,10)$. HS also binds to molecules expressed on the cell surface, such as selectins, and this interaction promotes a strong adhesion to stop the rolling 
leukocytes and enable their transmigration out of the blood vessel (10). Thus, increased expression of HS has been linked to a sustained inflammatory response and leukocyte recruitment to the inflammatory tissue. Heparin-based drugs or glycosaminoglycan mimics, therefore, are designed to interfere with HS-protein interactions to compete for the functions of HS side chains. These compounds have been shown to have antiinflammatory effects and to benefit patients with bronchial asthma, ulcerative colitis, and skin injuries, including burns (6).

Studies regarding the pathology of asthma show that bronchial fibroblasts derived from asthmatic subjects have significantly higher levels of proteoglycans such as hyaluronan, perlecan, versican, small HSPGs, and biglycan (11). In addition, HS side chains of HSPGs play a critical role in airway hyperresponsiveness and inflammation. The lack of a gene encoding $N$-deacetylase/ $N$-sulfotransferase- 1 (Ndst1), a key enzyme involved in the biosynthesis of HS side chains, or anti-HS antibody treatment in lung endothelial cells decreases allergen-induced airway hyperresponsiveness and inflammation via a significant reduction in airway recruitment of inflammatory cells such as eosinophils, macrophages, neutrophils, and lymphocytes (12). Therefore, HS side chains of HSPGs can serve as potential biomarkers that may be targeted with suitable imaging reagents for the diagnosis, prognostication, and monitoring of responses to therapy of airway hyperresponsiveness and inflammation.

We previously reported that HSPGs are essential cellular receptors for eosinophil cationic protein (ECP) (13). HS side chains of HSPGs mediate ECP binding to target cells with subsequent lipid raft-associated macropinocytosis of ECP. On the basis of this finding, we hypothesized that radioiodine-labeled recombinant ECP ( $\left.{ }^{123} \mathrm{I}-\mathrm{rECP}\right)$ could serve as an imaging probe for HS side chains of HSPGs in vivo. In this study, we evaluated ${ }^{123} \mathrm{I}$-rECP for monitoring HS side chains of HSPGs in an allergen-induced asthma model using small-animal SPECT imaging, biodistribution measurements, and microautoradiography.

\section{MATERIALS AND METHODS}

\section{Preparation of rECP}

The production of $\mathrm{rECP}$ has been described elsewhere (14). Briefly, human ECP complementary DNA was isolated and cloned into pET23a(+) plasmid. The recombinant plasmids were transformed into Escherichia coli BL21(DE3) cells for protein expression. The bacteria were harvested at $24 \mathrm{~h}$ after induction by adding isopropyl$\beta$-D-thiogalactopyranoside, and the rECP inclusion bodies could be isolated and purified using His-Bind affinity column chromatography (Novagen). After refolding, the rECP was concentrated and sorted in $50 \mathrm{mM} \mathrm{NaOAc}\left(\mathrm{pH} \mathrm{5.0)}\right.$ ) at $4^{\circ} \mathrm{C}$.

\section{Radiolabeling}

rECP proteins were radioiodinated with ${ }^{125} \mathrm{I}$ or ${ }^{123} \mathrm{I}$ by the Chloramine-T (Sigma-Aldrich) method. Five micrograms of ECP, $150 \mathrm{MBq}$ of ${ }^{125} \mathrm{I}$ or ${ }^{123} \mathrm{I}$, and $10 \mu \mathrm{g}$ of Chloramine-T were added, and the solution was mixed for $45 \mathrm{~s}$. Subsequently, $24 \mu \mathrm{g}$ of sodium metabisulfite $(2.4 \mathrm{mg} / \mathrm{mL})$ was added to stop the labeling reaction, and the solution was again mixed for $45 \mathrm{~s}$. The radiolabeled probe was purified using a PD10 column (GE, Sweden) with $250-\mu \mathrm{L}$ fractions eluted with a phosphate buffer. Radiochemical purity was assessed by radio-high-performance liquid chromatography on a BioSilect SEC column (Bio-Rad Laboratories) using potassium phosphate $(0.01 \mathrm{~mol} / \mathrm{L})$ as the eluent at a flow rate of $1 \mathrm{~mL} / \mathrm{min}$.

\section{Cell Cultures}

Beas-2B (human bronchial epithelial cell line) and A549 (human lung adenocarcinoma epithelial cell line) were cultured in RPMI 1640 medium (Sigma-Aldrich) supplemented with $10 \%$ fetal bovine serum (FBS). CHO $K_{1}$ (Chinese hamster ovary cell line) and $\mathrm{CHO}$ pgs A-745 (Chinese hamster ovary cell line with genetically deficient in proteoglycan biosynthesis) cells were cultured in Vitacel Ham's F12K medium (Sigma-Aldrich) supplemented with 10\% FBS.

\section{In Vitro Binding Assays}

Beas-2B cells were seeded into 96 -well plates at $1 \times 10^{4}$ cells per well and incubated overnight at $37^{\circ} \mathrm{C}$. Serial dilutions of rECP were added, and ${ }^{125} \mathrm{I}$-rECP was also treated into 96-well plates with the same concentration. The plate was then incubated for $1 \mathrm{~h}$ at $37^{\circ} \mathrm{C}$, washed, and dried, and then $0.1 \mathrm{~mL}$ of $2 \mathrm{~N} \mathrm{NaOH}$ was added to each well to facilitate cell homogenization. The lysates were collected and counted using a $\gamma$-counter (Packard; Cobra). The rECP concentration, which reduces specific binding by $50 \%$ (IC50), was calculated by Sigma Plot (Jandel Scientific). All the experiments were done in triplicate.

\section{Scatchard Analysis}

Scatchard analysis was performed to determine the dissociation constant $\left(\mathrm{K}_{\mathrm{d}}\right)$ and binding maximum $\left(\mathrm{B}_{\max }\right)$ for ${ }^{125} \mathrm{I}-\mathrm{rECP}$ on Beas-2B cells. Cells were cultured to confluence in 6-well plates and incubated for $2 \mathrm{~h}$ at $4{ }^{\circ} \mathrm{C}$ with increasing concentrations of ${ }^{125} \mathrm{I}$-rECP $(0.03-30 \mathrm{nM})$ in $1 \mathrm{~mL}$ of binding buffer. Nonspecific binding was determined by coincubation with an excess of $1 \mu \mathrm{M}$ unlabeled rECP. After incubation, cells were washed with phosphatebuffered saline (PBS), and the cell-associated activity was measured in a shielded well-type $\gamma$-counter. The corresponding values of $\mathrm{K}_{\mathrm{d}}$ and $\mathrm{B}_{\max }$ were generated by curve-fitting of the saturation plots with application of the GraphPad Prism program (version 5.0; GraphPad Software).

\section{Cell Uptake and HS-Blocking Studies}

Cells $\left(10^{6}\right.$ per dish) were incubated with ${ }^{125} \mathrm{I}-\mathrm{rECP}(2 \mathrm{nM})$ at $37^{\circ} \mathrm{C}$ from 0.5 to $4 \mathrm{~h}$. At each time point, the corresponding plate was removed, the radioactive medium was aspirated, and the cells were washed with PBS. After being washed, the plate was dried and $0.1 \mathrm{~mL}$ of $2 \mathrm{~N} \mathrm{NaOH}$ was added to the wells to facilitate cell lysis. The lysates were collected and counted in a $\gamma$-counter. For HSblocking studies, cells were incubated for $2 \mathrm{~h}$ at $37^{\circ} \mathrm{C}$ in the presence or absence of heparinase III at the final concentration of $2.4 \mathrm{U} / \mathrm{mL}$ in RPMI 1640 medium or were grown in the medium containing sodium chlorate $(70 \mathrm{mM})$ for $24 \mathrm{~h}$. Cells were processed for the cell uptake assay as described above. For the endogenous circulating ECP competition studies, cells were incubated with FBS, allergic human serum, or normal human serum with ${ }^{125} \mathrm{I}-\mathrm{rECP}(2 \mathrm{nM})$ for $1.5 \mathrm{~h}$ at $37^{\circ} \mathrm{C}$. The levels of endogenous circulating ECP in normal human serum and allergic human serum were $6.15 \mu \mathrm{g} / \mathrm{L}$ (total amount, $12.3 \mathrm{ng}$ ) and $51.32 \mu \mathrm{g} / \mathrm{L}$ (total amount, $102.64 \mathrm{ng}$ ), respectively, determined using an ECP enzyme-linked immunosorbent assay kit (MBL). The cell uptake of ${ }^{125} \mathrm{I}-\mathrm{rECP}$ was measured as described above. All the experiments were done in triplicate. 


\section{Biodistribution Studies}

Biodistribution studies in control mice were performed on female BALB/c mice aged 6-8 wk (Animal Facility of the National Science Counsel). Animals received $37 \mathrm{kBq}$ of ${ }^{125} \mathrm{I}-\mathrm{rECP}$ in $100 \mu \mathrm{L}$ of PBS via lateral tail vein injection, and then were euthanized by $\mathrm{CO}_{2} / \mathrm{O}_{2}$ asphyxiation at specified time points $(1,2,3$, and $24 \mathrm{~h}, n=6)$. After sacrifice, selected tissues and organs of interest were then removed and weighed, and the radioactivity was measured using a $\gamma$-counter. The percentage injected dose per gram $(\% \mathrm{ID} / \mathrm{g})$ was then calculated. In the heparinase III treatment group, asthma or normal mice were injected twice $(0$ and $8 \mathrm{~h})$ via the lateral tail vein with PBS ( $\mathrm{pH} 7.3$ ) containing 0.05 IU heparinase III or with PBS alone. At $24 \mathrm{~h}$ after the first injection, mice were used for biodistribution studies or SPECT imaging. All animal experiments were conducted according to institutional guidelines of China Medical University after permission was acquired from the local Ethical Committee for Animal Experimentation.

\section{Asthma Model}

Female BALB/c mice aged 6-8 wk were sensitized by intraperitoneal injection of $50 \mathrm{mg}$ of ovalbumin emulsified with $4 \mathrm{mg}$ of aluminum hydroxide (Pierce Chemical) in a total volume of 200 $\mu \mathrm{L}$ on days 0,14 , and 28 , and then challenged with ovalbumin $(100 \mu \mathrm{g}$ in a total volume of $50 \mu \mathrm{L})$ by intranasal administrations on days 39, 40, and 41. SPECT imaging and biodistribution studies were performed on day 42 .

\section{SPECT Imaging}

Asthma and control mice were injected with $20 \mathrm{MBq}$ of ${ }^{123} \mathrm{I}-\mathrm{rECP}$. One hour after injection, mice were scanned on an animal SPECT/ PET/CT device (Triumph Trimodality system; Gamma Medica) under isoflurane anesthesia. Static images (30 $\mathrm{min})$ were obtained with a zoom factor of 2 in a $256 \times 256$ matrix. The SPECT imaging was followed by CT image acquisition (x-ray source, $50 \mathrm{kV}, 0.4 \mathrm{~mA}$; 256 projections), with the animal in exactly the same position. SPECT and CT images were coregistered using PMOD software (PMOD Technologies Ltd.). Calculations were corrected for radiation decay of ${ }^{123} \mathrm{I}$ and the amount of injected dose, and the consistent color scale was applied to all SPECT images.

\section{Immunohistochemistry}

Tissues were fixed in $4 \%$ paraformaldehyde (Sigma-Aldrich) and paraffin-embedded. Tissue sections were deparaffinized and hydrated through a sequential alcohol series before staining. Ten-micrometer sections were immunostained with the monoclonal antibody against HS (U.S. Biologica) or ECP (15), visualized with an AEC kit (InnoGenex), and counterstained with hematoxylin.

\section{Microautoradiography}

Microautoradiography was used to confirm the presence of cellular uptake of ${ }^{125} \mathrm{I}-\mathrm{rECP}$ and to further investigate localization of uptake cells at histologic analysis. The melted Ilford K5 emulsion (Ilford Imaging) was poured onto the tissue sections, previously treated by $\mathrm{HS}$ immunohistochemistry procedures for $5 \mathrm{~s}$ at $50^{\circ} \mathrm{C}$ in a dark room, and then stored at $-70^{\circ} \mathrm{C}$ for $1 \mathrm{wk}$ in dehydrated and light-tight boxes. The slides were then developed using Kodak photographic developer D-19 (Eastman Kodak Co.) for 6 min and fixed using a photographic fixer before they were viewed with light microscopy.

\section{Leukocyte Infiltration Analysis}

Lungs were perfused with $10 \mathrm{~mL}$ of PBS through the right ventricle. Lungs were cut into small pieces and disrupted through a metal sieve. The red blood cells were lysed by ACK (ammonium-chloride-potassium) lysis buffer (1.6 g of $\mathrm{NH}_{4} \mathrm{Cl}$, $0.2 \mathrm{~g}$ of $\mathrm{KHCO}_{3}$, and $0.03 \mathrm{~g}$ of ethylenediaminetetraacetic acid in $100 \mathrm{~mL}$ of $\mathrm{DDH}_{2} \mathrm{O}$ ), and the filter was used to remove debris. The single-cell suspension was resuspended in PBS and 5\% fetal calf serum containing $0.01 \%$ sodium azide and incubated with anti-FcR (2.4G2) for 20 min on ice. Next, cells were stained with biotinylated CD45 antibody (30-F11; PharMingen) for $30 \mathrm{~min}$ on ice, and then stained with Streptavidin PE (eBioscience) for $20 \mathrm{~min}$ on ice. Cells were washed and analyzed by FACScanto (BD Bioscience). Data were analyzed using the FACSDiva software (BD Bioscience)

\section{Statistical Analysis}

For multiple comparisons of nonparametric variables, KruskalWallis ANOVA was used. For parametric variables, ANOVA was used along with Fisher least-significant-difference. For data correlation, simple regression analysis was performed to establish the correlation among ${ }^{125} \mathrm{I}$-rECP uptake, HS amount, and leukocyte infiltration. A $P$ value derived from a 2-tailed Student $t$ test less than 0.05 was considered significant.

\section{RESULTS}

\section{Radiochemical Purity and Stability of ${ }^{123}$ - or ${ }^{125}$ I-rECP}

Using the Chloramine-T method, we obtained ${ }^{125} \mathrm{I}$ - or ${ }^{123} \mathrm{I}$-ECP at radiochemical yields of $84.0 \% \pm 3.1 \%$. After purification of the radioligand using a PD10 column, radiochemical purities of both ${ }^{125} \mathrm{I}$ - and ${ }^{123} \mathrm{I}$-labeled rECP were greater than $95 \%$, as shown by radio-high-performance liquid chromatography analysis at $24 \mathrm{~h}$ after labeling (Supplemental Fig. 1; supplemental materials are available online only at http://jnm.snmjournals.org). On average, specific radioactivity was in the range of $26.3 \pm 2.4 \mathrm{MBq} / \mu \mathrm{g}$ of protein. The radiochemical purity after incubation in human or mouse sera at $37^{\circ} \mathrm{C}$ was more than $90 \%$ at $4 \mathrm{~h}$, indicating the high stability in vivo. The IC50 of ${ }^{125}$ I-rECP was $7.4 \pm 0.1 \mathrm{nM}$ (Fig. 1). Moreover, Scatchard analysis revealed that the $\mathrm{K}_{\mathrm{d}}$ of ${ }^{125} \mathrm{I}-\mathrm{ECP}$ was $8.28 \pm 0.035 \mathrm{nM}$,



FIGURE 1. Competitive binding curve of IC50 determination of ${ }^{125} \mathrm{I}-\mathrm{rECP}$ in Beas-2B cells. Serial dilutions of rECP and ${ }^{125} \mathrm{I}-\mathrm{rECP}$ were added into 96-well plates with same concentration. Each point represents mean $\pm \mathrm{SD}$ of triplicate measurements. 
and the $\mathrm{B}_{\max }$ on Beas-2B cells was $1.54 \times 10^{6} \pm 0.5 \times 10^{6}$ per cell (Supplemental Fig. 2).

\section{In Vitro Cellular Uptake of ${ }^{125}$ I-rECP}

Data concerning the uptake of ${ }^{125} \mathrm{I}-\mathrm{rECP}$ by the Beas-2B cell line are presented in Figure 2A. The uptake was rapid, reaching a plateau after $1.5 \mathrm{~h}$ of incubation. To determine the association between $\mathrm{rECP}$ and HS proteoglycans, we investigated the uptake of ${ }^{125} \mathrm{I}$-rECP in 3 HS proteoglycanpositive cell lines (Beas-2B, A549, and $\mathrm{CHO} K_{1}$ ) and
1 negative cell line (CHO pgs A-745). The significant ${ }^{125}$ I-rECP uptake was observed in Beas-2B, A549, and CHO $K_{1}$ cells (Fig. 2B). However, CHO pgs A-745 cells showed no significant ${ }^{125} \mathrm{I}$-rECP uptake. We further investigated whether sulfation and the HS side chains of HSPGs were required for ${ }^{125} \mathrm{I}$-rECP uptake. The cell uptake assay was performed in the presence of chlorate, which competitively inhibits the formation of $3^{\prime}$-phosphoadenosine $5^{\prime}$ phosphosulfate, the high-energy sulfate donor in cellular sulfation reactions, thus preventing sulfation of glycoproteins
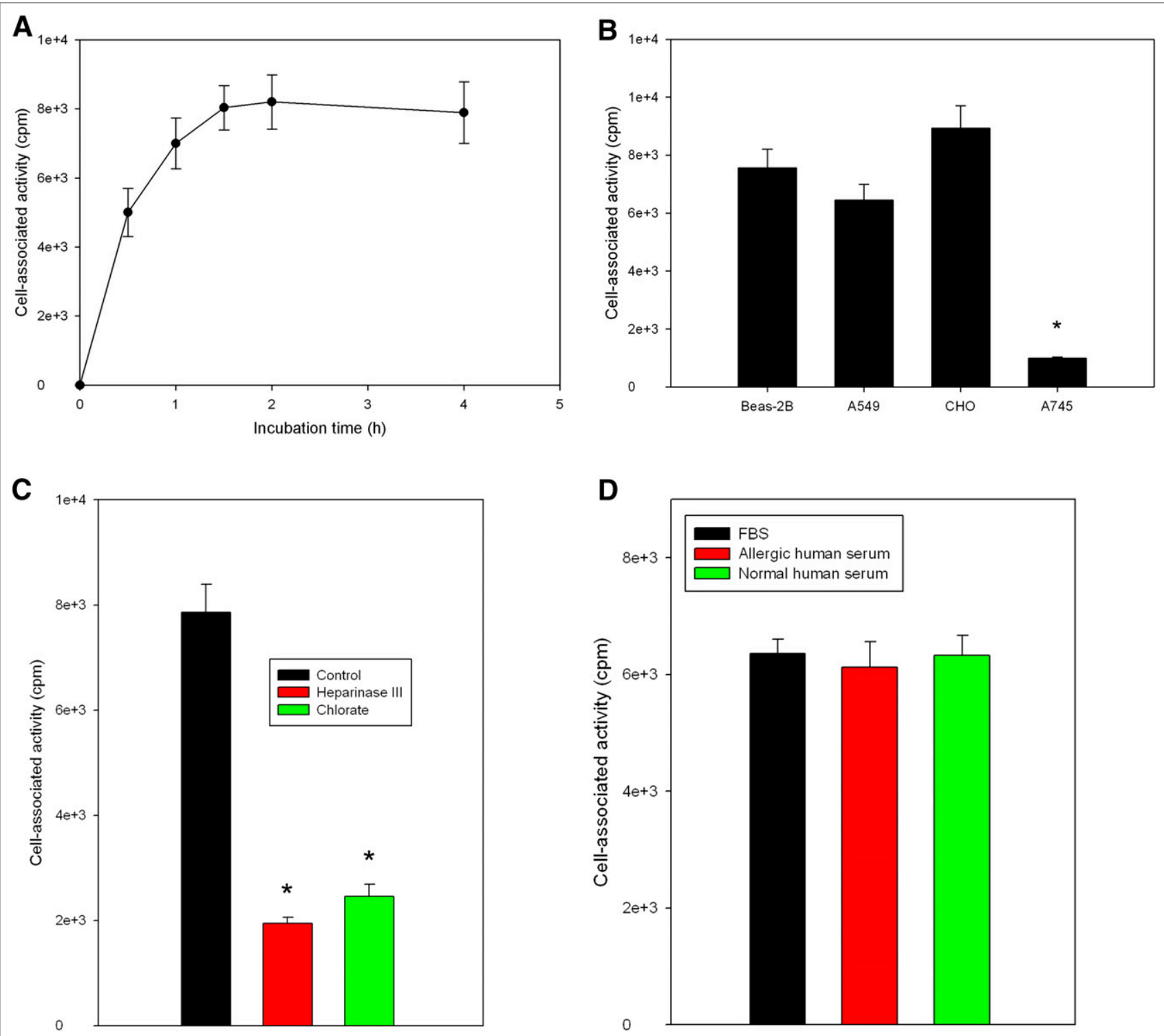

FIGURE 2. (A) Time course of ${ }^{125} \mathrm{I}-\mathrm{rECP}$ uptake in Beas-2B cells. Cells were incubated with ${ }^{125} \mathrm{I}-\mathrm{rECP}$ from 0.5 to $4 \mathrm{~h}$. (B) Uptake of ${ }^{125} \mathrm{I}-\mathrm{rECP}$ in HS proteoglycan-positive and HS proteoglycan-negative cell lines. HS proteoglycan-positive cells (Beas-2B, A549, and CHO $\left.K_{1}\right)$ and $\mathrm{HS}$ proteoglycan-negative cells $\left(\mathrm{CHO}\right.$ pgs A-745) were incubated with ${ }^{125} \mathrm{I}-\mathrm{rECP}$, and cellular uptake was assessed at $1.5 \mathrm{~h}$ after incubation. ${ }^{*} P<0.01$, as compared with $\mathrm{CHO} K_{1}$ cells. (C) Uptake of ${ }^{125} \mathrm{I}-\mathrm{rECP}$ in Beas-2B cells with or without pretreatment with chlorate or heparinase III. Cells were cultured for $24 \mathrm{~h}$ in absence or presence of sodium chlorate or treated with or without heparinase III before ${ }^{25} \mathrm{I}$-rECP uptake assay. (D) Uptake of ${ }^{125} \mathrm{I}-\mathrm{rECP}$ in Beas-2B cells with various serums. Cells were incubated with FBS, allergic human serum, or normal human serum with ${ }^{125} \mathrm{I}-\mathrm{rECP}(2 \mathrm{nM})$ for $1.5 \mathrm{~h}$ at $37^{\circ} \mathrm{C}$. Levels of endogenous circulating ECP in allergic human serum and normal human serum were 51.32 and $6.15 \mu \mathrm{g} / \mathrm{L}$, respectively. ${ }^{\star} P<0.01$, compared with control. Each point or bar represents mean \pm SD of triplicate measurements. 
and carbohydrates. ${ }^{125} \mathrm{I}$-rECP uptake in Beas-2B cells with chlorate treatment was markedly decreased (Fig. 2C). Furthermore, cellular uptake of ${ }^{125} \mathrm{I}-\mathrm{rECP}$ was also inhibited after pretreatment with heparinase III, which selectively cleaves HS side chains of HSPGs from cellular surfaces. In addition, no significant difference was found among FBS, allergic human serum, and normal human serum for cell uptake of ${ }^{125} \mathrm{I}$-rECP, suggesting that the competition effect between endogenous circulating ECP and ${ }^{125} \mathrm{I}-\mathrm{rECP}$ is low (Fig. 2D). Also, the percentage occupancy of ${ }^{125}$ I-rECP was $19.45 \%$ and of endogenous ECP $29.2 \%$. Taken together, these results indicate that HS side chains of HSPGs act as the major cellular receptor for ${ }^{125} \mathrm{I}-\mathrm{rECP}$ uptake.

\section{Biodistribution and SPECT/CT Imaging of ${ }^{123}$-rECP in Normal Mice}

The results of the biodistribution studies in normal mice are summarized in Figure 3. These measurements, which track the total amount of radioiodine retained in a tissue sample, showed a rapid clearance from the bloodstream. There were low radioactivity levels in the brain $(0.22 \% \pm$ $0.04 \% \mathrm{ID} / \mathrm{g}$ ), indicating a limitation for penetration of ${ }^{125} \mathrm{I}-\mathrm{rECP}$ across the blood-brain barrier. At $1 \mathrm{~h}$ after injection, ${ }^{125} \mathrm{I}$-rECP was retained in the lungs $(2.98 \% \pm 0.24$ $\% \mathrm{ID} / \mathrm{g})$, liver $(3.54 \% \pm 0.63 \% \mathrm{ID} / \mathrm{g})$, stomach $(45.53 \% \pm$ $2.14 \% \mathrm{ID} / \mathrm{g})$, pancreas $(4.32 \% \pm 0.52 \% \mathrm{ID} / \mathrm{g})$, spleen $(8.12 \% \pm 0.43 \% \mathrm{ID} / \mathrm{g})$, small intestine $(7.16 \% \pm 0.35 \% \mathrm{ID} / \mathrm{g})$, and kidneys $(23.54 \% \pm 3.32 \% \mathrm{ID} / \mathrm{g})$, in comparison with the muscle $(1.64 \% \pm 0.13 \% \mathrm{ID} / \mathrm{g})$. However, retention levels fully disappeared at $24 \mathrm{~h}$ after injection. Moreover, mice with heparinase III treatment showed significantly decreased ${ }^{125}$ I-rECP accumulation in the lungs, liver, stomach, pancreas, spleen, small intestine, thyroid, and kidneys, as compared with the control mice, suggesting that in vivo protein trafficking of circulating $\mathrm{rECP}$ is dependent on the

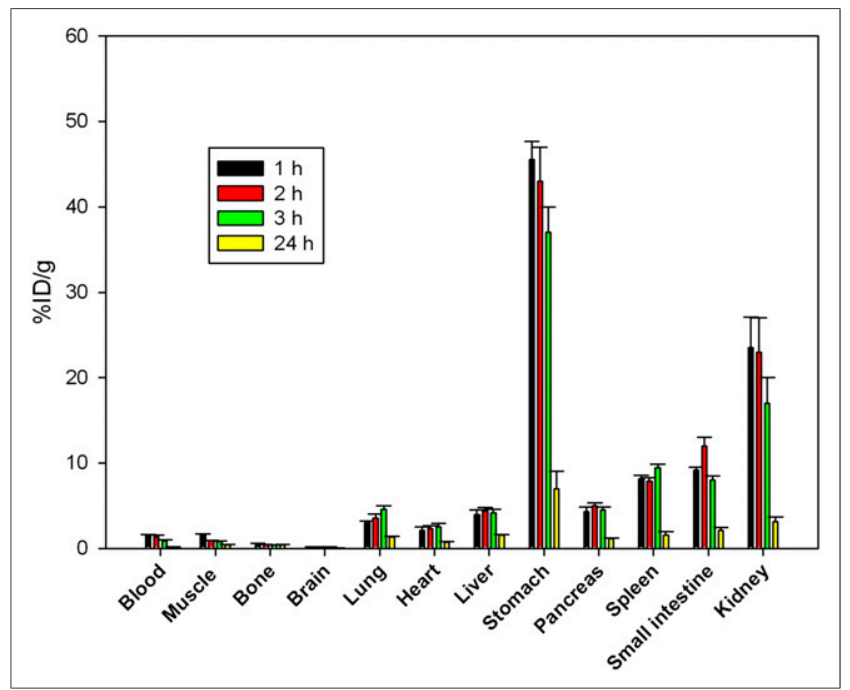

FIGURE 3. Biodistribution of ${ }^{125} \mathrm{I}-\mathrm{rECP}$ in normal mice at variable time points. Bars report mean $\pm \mathrm{SD}, n=6$ mice.
TABLE 1

Biodistribution of Radioiodinated rECP in Mice With or Without Heparinase III Treatment

\begin{tabular}{|c|c|c|c|}
\hline Tissue & $\begin{array}{l}\text { Without heparinase } \\
\text { III (\%ID/g) }\end{array}$ & $\begin{array}{l}\text { With heparinase } \\
\text { III (\%ID/g) }\end{array}$ & $\begin{array}{c}P \\
\text { (t test) }\end{array}$ \\
\hline Blood & $1.35 \pm 0.23$ & $1.85 \pm 0.33$ & 0.011 \\
\hline Muscle & $1.64 \pm 0.13$ & $1.24 \pm 0.05$ & $<0.001$ \\
\hline Bone & $0.63 \pm 0.05$ & $0.74 \pm 0.04$ & $<0.001$ \\
\hline Brain & $0.22 \pm 0.04$ & $0.21 \pm 0.05$ & $>0.050$ \\
\hline Lung & $2.98 \pm 0.24$ & $1.26 \pm 0.65$ & $<0.001$ \\
\hline Heart & $2.51 \pm 0.32$ & $1.31 \pm 0.24$ & $<0.001$ \\
\hline Liver & $3.54 \pm 0.63$ & $1.86 \pm 0.42$ & $<0.001$ \\
\hline Stomach & $45.53 \pm 2.14$ & $34.32 \pm 5.12$ & $<0.001$ \\
\hline Pancreas & $4.32 \pm 0.52$ & $2.14 \pm 0.12$ & $<0.001$ \\
\hline Spleen & $8.12 \pm 0.43$ & $2.55 \pm 0.33$ & $<0.001$ \\
\hline Small intestine & $7.16 \pm 0.35$ & $4.53 \pm 0.72$ & $<0.001$ \\
\hline Kidney & $23.54 \pm 3.32$ & $15.54 \pm 1.41$ & $<0.001$ \\
\hline Thyroid & $15.32 \pm 2.13$ & $10.53 \pm 3.23$ & 0.016 \\
\hline
\end{tabular}

Data represent mean $\pm S D$ of values obtained from 6 mice.

distribution of HS side chains of HSPGs (Table 1). In agreement with the biodistribution data, substantial accumulation of ${ }^{125} \mathrm{I}$-rECP was noted in the stomach, kidneys, thyroid, and nasal cavity, which was clearly visualized at $1 \mathrm{~h}$ after injection by small-animal SPECT/CT imaging (Supplemental Fig. 3). Collectively, these data suggest that the biodistribution of circulating rECP is specifically localized within the body and that HS side chains of HSPGs mediate circulating rECP trafficking in vivo.

\section{Comparison of Lung Biodistribution and SPECT/CT Imaging of ${ }^{123}$ I-rECP in Normal and Asthma Mice}

To determine whether ${ }^{123} \mathrm{I}$-rECP can serve as a potential imaging probe for clinical diagnostic imaging in airway hyperresponsiveness and inflammation, a murine asthma model was used. These asthma mice exhibited airway hyperresponsiveness and inflammation, as shown in previous studies (16). ${ }^{123} \mathrm{I}-\mathrm{rECP}$ was injected into either asthma or normal mice for analysis by both SPECT/CT imaging and biodistribution in lung tissues. The results from SPECT/CT imaging demonstrated that an appreciably higher accumulation of radioactive substances in the lungs in asthma mice than in normal mice was visualized at $1 \mathrm{~h}$ after injection of ${ }^{123} \mathrm{I}$-rECP (Fig. 4A). Ex vivo biodistribution studies in the lungs also confirmed that there was at least a 4-fold increase in uptake in the asthma mice, as compared with normal mice (Fig. 4B). However, asthma mice that received heparinase III treatment showed a significant inhibition of ${ }^{123} \mathrm{I}-\mathrm{rECP}$ accumulation in lung tissues, as compared with asthma mice without heparinase III treatment (Figs. 4A and 4B). These results indicate that inflammatory tissues attract and accumulate circulating rECP and that the HS side chains of HSPGs are required for ovalbumin-induced airway inflammation-induced ${ }^{123} \mathrm{I}-\mathrm{rECP}$ retention in lung tissues. 
FIGURE 4. (A) SPECT/CT imaging of lungs in asthma and normal mice with or without heparinase III treatment at $1 \mathrm{~h}$ after injection of ${ }^{123} \mathrm{I}-\mathrm{rECP}$. (B) Comparison of ${ }^{125} \mathrm{I}-\mathrm{rECP}$ accumulation in lungs of asthma and normal mice with or without heparinase III treatment at $1 \mathrm{~h}$ after injection. ${ }^{\star} P<0.01$, compared with normal mice. $\# P<0.01$, compared with without heparinase III treatment. Bars report mean $\pm \mathrm{SD}, n=6$ mice.

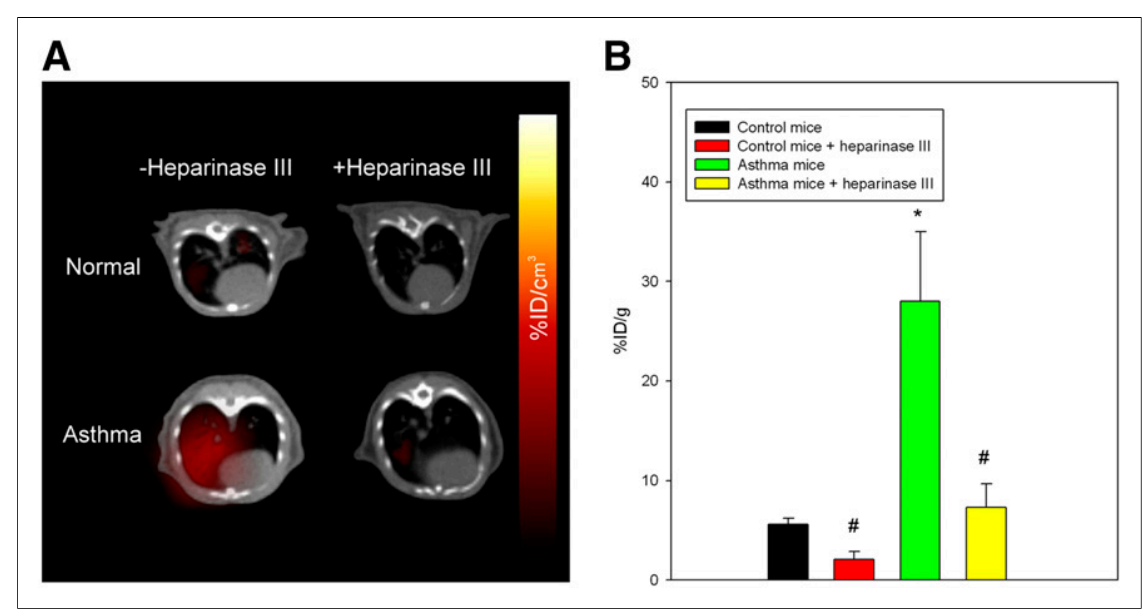

\section{Immunohistochemistry Validates HS Expression in Normal and Asthma Mice}

The expression and location of HS and rECP in lung tissues of normal and asthma mice were observed by an immunohistochemical analysis. As shown in Supplemental Figure 4, lung tissues from asthma mice, as compared with normal mice, had a significant increase in HS expression. An increase in rECP accumulation was also observed in the asthma mice. However, HS and rECP staining was abolished after injection of heparinase III. HS was observed in endothelial cells, alveolar epithelial cells, and macrophages in lung parenchyma. HS was detected in a linear distribution on endothelial basement membranes where it was found in abundance in asthmatic lung tissue. rECP showed a similar pattern and correlated well with the location of HS in lung tissue. In addition, microautoradiography results demonstrated that silver grains in the lung tissue were distributed over HSexpressing cells, indicating the specificity of ${ }^{125} \mathrm{I}-\mathrm{rECP}$ for binding to HS within tissues at the cellular level (Fig. 5).

\section{Correlation Between ${ }^{125}$ I-rECP Accumulation and Leukocyte Infiltration}

The complex pathophysiology of allergic lung inflammation and bronchial hyperresponsiveness that characterizes asthma is due to the regulated accumulation and activation of different subsets of leukocytes in the lungs. HS side chains of HSPGs are essential for leukocyte recruitment during inflammation (10). Therefore, because of the elevated HS in tissues with inflammation, we investigated whether ${ }^{125} \mathrm{I}-\mathrm{rECP}$ accumulation can reflect leukocyte infiltration. These results show that leukocyte infiltration was significantly elevated in the lungs of asthma mice (Fig. 6A). ${ }^{125} \mathrm{I}-\mathrm{rECP}$ accumulation was linearly correlated with leukocyte infiltration (Fig. 6B) in lungs from normal and asthma mice, indicating that ${ }^{125} \mathrm{I}-\mathrm{rECP}$ accumulation is associated with severity of leukocyte infiltration.

\section{DISCUSSION}

ECP is a single-chain, zinc-containing small protein released by activated eosinophils and is, presently, the most widely used clinical biomarker of eosinophil activity in asthma $(17,18)$. The previous discovery that ECP is synthesized in eosinophil progenitors in human bone marrow and stored in specific granules in mature peripheral blood eosinophils (19) had facilitated speculation of eosinophilmediated trafficking and biodistribution of ECP in vivo. However, the biodistribution and metabolism of circulating ECP secreted by activated eosinophils in living subjects is still unclear. In the current study, we have for the first time, to our knowledge, evaluated the biodistribution and metabolism of circulating ECP in living subjects using radioiodinelabeled rECP. Biodistribution and SPECT imaging of ${ }^{125} \mathrm{I}$ - or ${ }^{123} \mathrm{I}-\mathrm{rECP}$ in normal mice demonstrated that circulating rECPs have specific compartments within the body, as evidenced by the uptake of circulating ${ }^{125} \mathrm{I}$ - or ${ }^{123} \mathrm{I}$-rECP in the lungs, liver, stomach, pancreas, spleen, small intestine, kidneys, and thyroid in comparison with muscle. Although these tissues are potential targets for circulating

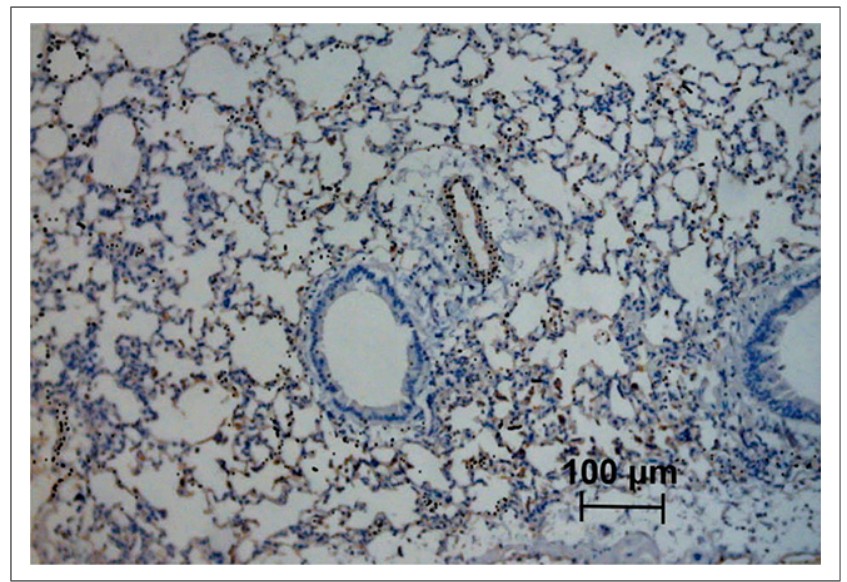

FIGURE 5. ${ }^{125} \mathrm{I}-\mathrm{rECP}$ microautoradiography of ovalbumin-induced airway inflammation combined with HS immunostaining. Asthma mice were intravenously injected with ${ }^{125}$ |-rECP and euthanized at $1 \mathrm{~h}$ after injection. Lung tissues were fixed, and slides were prepared for microautoradiography and HS immunostaining. Black silver grains indicate position of ${ }^{125}$ I. Original magnification, $\times 200$; bar, $100 \mu \mathrm{m}$. 




FIGURE 6. (A) Comparison of leukocyte infiltration in lungs from asthma and normal mice. Total leukocytes $\left(C D 45^{+}\right.$cells) were determined using flow cytometry. (B) Correlation between ${ }^{125} \mathrm{I}-\mathrm{rECP}$ accumulation and leukocyte infiltration $\left(R^{2}=0.87, P=0.0001\right.$, $n=13)$.
rECP in vivo, the relatively high values in the stomach, kidneys, and thyroid may be due to renal catabolism and dehalogenation of radioiodine-labeled rECP, accompanied by sequestration of the free iodide in the stomach and thyroid. Another reason could be the systemic deiodination-mediated nonspecific uptake of free iodine in these tissues. Additionally, because the stomach and kidneys are rich sources of HSPGs, it is likely that some of the radioiodine-labeled rECPs are specifically bound to structures within these tissues.

We have previously shown that the binding and endocytosis of ECP into bronchial epithelial cells was highly dependent on HSPGs (13). Here, the results derived from in vitro studies also suggest that HSPGs act as the major cellular receptor for ${ }^{125} \mathrm{I}-\mathrm{rECP}$ uptake. The requirement of structural recognition for binding was supported by the observation that uptake of ${ }^{125}$ I-rECP was severely impaired in the pgs D-677 cells, which do not produce HS side chains but have 3 times more chondroitin sulfate than the wildtype $\mathrm{CHO} K_{1}$ cells. Moreover, cells treated with chlorate or heparinase III showed markedly decreased ${ }^{125}$ I-rECP uptake. These results indicate that the cellular uptake of rECP via HS binding was unaffected by radioiodination. In addition, we provided in vivo evidence to support this notion. Mice treated with heparinase III showed significantly less ${ }^{123} \mathrm{I}-$ rECP accumulation in the lungs, liver, stomach, pancreas, spleen, small intestine, and kidneys. Many of these tissues have been shown to contain HS (20), suggesting that in vivo protein trafficking of circulating ECP is dependent on HS distribution. Using a combination of microautoradiography and immunocytochemistry with ${ }^{125} \mathrm{I}-\mathrm{rECP}$ and antibody against HS, we found ${ }^{125} \mathrm{I}-\mathrm{rECP}$ accumulation to be colocalized with HS-expressing cells in tissues. Taken together, these findings collectively provide evidence supporting the fact that circulating ECP is specifically distributed and trafficked in vivo. Thus, HS side chains of HSPGs are required for ${ }^{125} \mathrm{I}$ - or ${ }^{123} \mathrm{I}$-rECP binding and uptake in vitro and in vivo.

Although the precise mechanism for regulating synthesis of HS in inflammation is not fully understood, HS structure and localization are altered after injury and during the various phases of inflammation $(9,21)$. These changes serve to modify the activity of HS-dependent soluble and cell-surface effectors of the inflammatory process. HS can undergo significant modifications during chain synthesis but also as a consequence of protein core processing of HSPGs (1). Studies have demonstrated that proteoglycan metabolism is altered in patients with asthma, because fibroblasts from afflicted individuals produce significantly higher levels of proteoglycans such as hyaluronan, perlecan, versican, small HSPGs, and biglycan (11). Furthermore, recent studies have demonstrated that endothelial-expressed HS plays a crucial role in allergic airway inflammation through the regulation of inflammatory cell recruitment to the airways by mediating the interaction of leukocytes with the vascular endothelium (12). In agreement with these findings, we detected increased HS expression in lungs from mice with ovalbumin-induced airway inflammation. This increased HS was observed in endothelial cells, alveolar epithelial cells, and macrophages. Furthermore, accumulation of ${ }^{125} \mathrm{I}-\mathrm{rECP}$ in the lungs was linearly correlated with leukocyte infiltration. We also noted that HS cleavage substantially reduced airway inflammation-mediated uptake of ${ }^{125} \mathrm{I}-\mathrm{rECP}$. Collectively, these results clearly show that inflammation-elevated $\mathrm{HS}$ is a critical mechanism for circulating rECP accumulation and leukocyte infiltration in living subjects.

In this work, we investigated the feasibility of using rECP for radionuclide molecular imaging of HS-expressing tissues in vivo. Although nonspecific uptake of free iodine caused by renal catabolism or deiodination may pose challenges for radioiodine-labeled rECP monitoring of HS side chains of HSPG expression in the stomach, kidneys, and thyroid, the background levels in blood, lungs, or other tissues are low, as shown by biodistribution and SPECT imaging. These results would make it possible to image inflammation-elevated HS expression in these tissues. Our results indicate that these regions are sufficiently distinguishable from the nontargeted organs and that these regions give high-contrast SPECT images at $1 \mathrm{~h}$ after injection. On the other hand, the inflammation-mediated blood flow or permeability changes may cause high accumulation of radioiodine-labeled rECP in the tissues with inflammation. However, asthma mice that received in vivo cleavage of HS side chains of HSPGs via heparinase III treatment showed 
a significant inhibition of ${ }^{123} \mathrm{I}-\mathrm{rECP}$ accumulation in lung tissues, as compared with asthma mice without heparinase III treatment. Moreover, the radioactivity in blood or other background tissues is low at $1 \mathrm{~h}$ after injection of ${ }^{125} \mathrm{I}-$ or ${ }^{123} \mathrm{I}$-rECP, indicating a rapid clearance rate of radioiodinelabeled rECP within the body. These results suggest that high accumulation of radioiodine-labeled $\mathrm{rECP}$ in the tissues with inflammation at $1 \mathrm{~h}$ after injection is specific for HS side chains of HSPG binding and is not dependent on blood flow or vascular permeability changes. For applications in patients, it is important to consider that endogenous circulating ECP may also compete with radioiodine-labeled rECP in binding the HS side chains of HSPGs. However, Beas-2B cells treated with human serum with elevated ECP derived from a patient with allergy showed no significant difference in ${ }^{125}$ I-rECP uptake, as compared with healthy human serum or FBS, indicating that this is not a concern for imaging applications. The possible explanations for these results are that the endogenous ECP concentration is far from saturating the HS or that the HS-binding affinity of radioiodine-labeled rECP is higher than that of endogenous circulating ECP.

Disease severity is carefully assessed to facilitate appropriate adjustments in pharmacologic treatment and to minimize unwanted effects while maintaining effective control of asthma in a patient. The measurement of lung function, symptoms, and reliever use has traditionally been used as an objective means of undertaking this assessment. However, the level of airway inflammation has not been quantified (22). Because asthma is primarily an inflammatory disorder, it would be desirable to measure the process of tissue inflammation when evaluating disease control. Therefore, a noninvasive measurement of airway inflammation in asthma would be a good approach for this purpose. The HS-binding ability, rapid loss of signal from unbound radiolabeled rECP, and a high linear correlation between tissue uptake of radiolabeled rECP and leukocyte infiltration support the evaluation of radiolabeled $\mathrm{rECP}$ as a potential imaging agent for the noninvasive, rapid detection, and monitoring of disease in patients with allergic lung inflammation. Furthermore, SPECT using radiolabeled $\mathrm{rECP}$ is critical for early and sensitive inflammation detection, patient selection for clinical trials based on in vivo HS expression quantification, and for better treatment monitoring and dose optimization based on the noninvasive detection of early responses to HSPG-targeted therapy.

\section{CONCLUSION}

This study has, for the first time to our knowledge, demonstrated that the biodistribution and metabolism of circulating $\mathrm{rECPs}$ in living subjects and inflammatory tissue caused accumulation of circulating rECPs via HS side chains of HSPGs. Our results showed that radiolabeled $\mathrm{rECP}$ is a novel imaging agent for HS side chains of HSPGs in predicting allergic lung inflammation in living mice. Further research is needed to determine whether this technique could be a useful clinical tool for the stratification of patients with asthma for HSPG-targeting therapy.

\section{DISCLOSURE}

The costs of publication of this article were defrayed in part by the payment of page charges. Therefore, and solely to indicate this fact, this article is hereby marked "advertisement" in accordance with 18 USC section 1734. This study was supported by grant NSC 99-2314-B-039-025-MY3 from the National Science Council, Taipei, Taiwan, and grants CMU98-N1-06 and CMU101S-17 from China Medical University, Taichung, Taiwan. No other potential conflict of interest relevant to this article was reported.

\section{ACKNOWLEDGMENT}

We thank the Molecular and Genetic Imaging Core/ NRPGM, Taiwan, for technical support.

\section{REFERENCES}

1. Sarrazin S, Lamanna WC, Esko JD. Heparan sulfate proteoglycans. Cold Spring Harb Perspect Biol. 2011;3:1-33.

2. Kirn-Safran C, Farach-Carson MC, Carson DD. Multifunctionality of extracellular and cell surface heparan sulfate proteoglycans. Cell Mol Life Sci. 2009;66: 3421-3434.

3. Bishop JR, Schuksz M, Esko JD. Heparan sulphate proteoglycans fine-tune mammalian physiology. Nature. 2007;446:1030-1037.

4. Teng YH, Aquino RS, Park PW. Molecular functions of syndecan-1 in disease. Matrix Biol. 2012;31:3-16.

5. Taylor KR, Gallo RL. Glycosaminoglycans and their proteoglycans: host-associated molecular patterns for initiation and modulation of inflammation. FASEB J. 2006;20:9-22.

6. Casu B, Naggi A, Torri G. Heparin-derived heparan sulfate mimics to modulate heparan sulfate-protein interaction in inflammation and cancer. Matrix Biol. 2010;29:442-452.

7. Lindahl U. Heparan sulfate-protein interactions: a concept for drug design? Thromb Haemost. 2007;98:109-115.

8. Tanaka Y, Kimata K, Adams DH, Eto S. Modulation of cytokine function by heparan sulfate proteoglycans: sophisticated models for the regulation of cellular responses to cytokines. Proc Assoc Am Physicians. 1998;110:118-125.

9. Parish CR. The role of heparan sulphate in inflammation. Nat Rev Immunol. 2006;6:633-643

10. Celie JW, Beelen RH, van den Born J. Heparan sulfate proteoglycans in extravasation: assisting leukocyte guidance. Front Biosci. 2009;14:4932-4949.

11. Westergren-Thorsson G, Chakir J, Lafreniere-Allard MJ, Boulet LP, Tremblay GM. Correlation between airway responsiveness and proteoglycan production by bronchial fibroblasts from normal and asthmatic subjects. Int J Biochem Cell Biol. 2002;34:1256-1267.

12. Zuberi RI, Ge XN, Jiang S, et al. Deficiency of endothelial heparan sulfates attenuates allergic airway inflammation. J Immunol. 2009;183:3971-3979.

13. Fan TC, Chang HT, Chen IW, Wang HY, Chang MD. A heparan sulfatefacilitated and raft-dependent macropinocytosis of eosinophil cationic protein. Traffic. 2007;8:1778-1795.

14. Wu CM, Chang HT, Chang MD. Membrane-bound carboxypeptidase E facilitates the entry of eosinophil cationic protein into neuroendocrine cells. Biochem J. 2004;382:841-848.

15. Pai TW, Su BH, Wu PC, et al. Unique peptide identification of RNase A superfamily sequences based on reinforced merging algorithms. J Bioinform Comput Biol. 2006;4:75-92.

16. Lee CC, Wang CN, Lai YT, et al. Shikonin inhibits maturation of bone marrowderived dendritic cells and suppresses allergic airway inflammation in a murine model of asthma. Br J Pharmacol. 2010;161:1496-1511.

17. Venge P, Bystrom J, Carlson M, et al. Eosinophil cationic protein (ECP): molecular and biological properties and the use of ECP as a marker of eosinophil activation in disease. Clin Exp Allergy. 1999;29:1172-1186.

18. Koh GC, Shek LP, Goh DY, Van Bever H, Koh DS. Eosinophil cationic protein: is it useful in asthma? A systematic review. Respir Med. 2007;101:696-705.

19. Venge P, Bystrom J. Eosinophil cationic protein (ECP). Int J Biochem Cell Biol. 1998;30:433-437.

20. Warda M, Toida T, Zhang F, et al. Isolation and characterization of heparan sulfate from various murine tissues. Glycoconj J. 2006;23:555-563.

21. Li JP, Vlodavsky I. Heparin, heparan sulfate and heparanase in inflammatory reactions. Thromb Haemost. 2009;102:823-828.

22. Murata A, Ling PM. Asthma diagnosis and management. Emerg Med Clin North Am. 2012;30:203-222. 